\title{
News and events
}

\section{9-20 September 1990, Oxford, UK The microstructure of cement and concrete}

The Materials Science Division of the Institute of Metals has issued the first announcement and call for papers for this meeting which is to take place at the University of Oxford. It is intended to provide common ground for practical scientists and engineers involved with cement and concrete as well ăs for research scientists.

The two-day meeting, co-sponsored by the Institute of Metals and the Institute of Ceramics, will provide an opportunity to explore facets of the problems associated with this topic and will also allow informal groups to discuss problems of particular relevance and assess the applicability of the techniques and models presented. Five major themes have been provisionally identified but papers on other topics under the general title of the meeting would be welcomed. The themes are: microstructure of traditional cements and concrete; microstructure of blanded cements; influence of chemical admixtures on the microstructure of cement and concrete; microstructures of novel cements; the effects of waste incorporations (e.g. radioactive or hazardous waste) on microstructural development.

Anyone wishing to submit a paper or who requires more information about this event should contact Ms A. M. Mullins, Conference Department ( $\mathrm{CC17}$ ), The Institute of Metals, 1 Carlton House Terrace, London SW1Y 5DB, U.K. Tel. 071-839 4071, telex 8814813, fax 071-8392289.

\section{1-25 January 1991, New Delhi, India} Cement and building materials

The third international NCB seminar on this subject will review progress in cement, lime and allied tech- nologies, and address issues of particular interest in developing countries and international technological collaboration. Themes include: productivity enhancement in operating plants, including energy conservation; modernization of manufacture of cement and allied building materials through improved techniques and installations; new technologies, processes, equipment and products; and performance and uses of cement and allied building materials.

Further information is available from Third NCB International Seminar, National Council for Cement and Building Materials, M10, South Extension II, Ring Road, New Delhi 110 049, India. Tel. 9111644 0133 , telex 03166261 , fax 91116448 .

\section{3-28 November 1992, New Delhi, India The chemistry of cement}

An inaugural meeting of the Scientific Organizing Committee was held at New Delhi in October 1989 to decide on the themes and plan of the Ninth International Congress on the Chemistry of Cement. The programme will consist of plenary lectures devoted to the themes and subthemes have been selected broadly to reflect progress since the eighth congress in Rio de Janeiro in 1986.

Further details, including the themes and subthemes, can be obtained from the Secretary General, Ninth International Congress on the Chemistry of Cement, 1992, National Council for Cement and Building Materials, M10, South Extension II, Ring Road, New Delhi 110 049, India. 